\title{
FAKTOR DETERMINAN DEPRESI POSTPARTUM DI WILAYAH KABUPATEN KLATEN JAWA TENGAH
}

\author{
Murwati $^{1}$, Suroso ${ }^{2}$, Sri Wahyuni ${ }^{3}$ \\ 1,2,3 Politeknik Kesehatan Kementerian Kesehatan Republik Indonesia \\ Email: murwati@gmail.com ${ }^{1}$, suroso@gmail.com ${ }^{2}$, sriwahyuni@gmail.com ${ }^{3}$
}

\begin{abstract}
Abstrak:
Ibu yang tidak berhasil menyesuaikan diri dengan peran barunya setelah melahirkan dapat mengalami gangguan psikologis seperti depresi postpartum. Prevalensi depresi postpartum diperkirakan berjumlah 1,9\% - 82,1\% di negara berkembang dan sekitar 5,2\% - 74,0\% di negara maju. Di Indonesia khususnya di Klaten Jawa Tengah ditemukan sebanyak 36\% kejadian depresi postpartum. Tujuan penelitian ini adalah untuk mengetahui faktor determinan depresi postpartum di wilayah Kabupaten Klaten Jawa Tengah. Sampel penelitian dengan menggunakan purposive consequtive sampling, yaitu ibu nifas hari ke-3 s.d ke-7 dan tidak ada riwayat penyakit menular serta gangguan jiwa. Jumlah sampel kasus yaitu 35 orang dan 70 sampel kontrol (1 : 2). Data di ambil dengan menggunakan kuesioner biodata dan EPDS atau Edinburg postnatal Depression Scale dengan uji Chi-square. Hasil penelitian menunjukkan ada hubungan antara umur ibu dengan kejadian depresi postpartum (umur $<20$ dan $>35$ tahun) saat melahirkan. Sedangkan pekerjaan, paritas, rencana mempunyai anak, riwayat persalinan, keberadaan orang yang membantu aktifitas sehari-hari, dan kelancaran ASI tidak berhubungan dengan kejadian depresi postpartum.
\end{abstract}

\begin{abstract}
:
Mothers who do not manage to adjust to their new role after giving birth can experience psychological disorders such as postpartum depression. The prevalence of postpartum depression is estimated at $1.9 \%-82.1 \%$ in developing countries and around $5.2 \%-74.0 \%$ in developed countries. In Indonesia, especially in Klaten, Central Java, 36\% of the incidence of postpartum depression was found. The purpose of this study was to determine the determinants of postpartum depression in the Klaten Regency, Central Java. The research sample using purposive consecutive sampling, namely postpartum mothers on the 3rd to 7th day and no history of infectious diseases and mental disorders. The number of case samples were 35 people and 70 control samples $(1: 2)$. Data were collected using a biodata questionnaire and EPDS or the Edinburgh Postnatal Depression Scale with Chi-square test. The results showed that there was a relationship between maternal age and the incidence of postpartum depression (age <20 and >35 years) during childbirth. Meanwhile, occupation, parity, plans to have children, history of childbirth, presence of people who help with daily activities, and smooth breastfeeding were not associated with the incidence of postpartum depression.
\end{abstract}

Keywords: Determinant Factor, Depression, Postpartum 


\section{PENDAHULUAN}

Depresi postpartum (DPP) adalah suatu depresi yang ditemukan pada perempuan setelah melahirkan, yang terjadi dalam kurun waktu 4 (empat) minggu, beberapa bulan bahkan beberapa tahun bila tidak diatasi dengan baik. DPP dapat terjadi mulai 6 minggu sampai 1 tahun (Bobak, 2005). Adapun ibu yang mengalami depresi postpartum jika tidak segera di tangani dapat berefek negatif terhadap keterikatan ibu anak dan perkembangan anak (Fitelson et al, 2011). Selain itu efek lainnya pada ibu adalah dapat menurunkan kemampuan dalam mengasuh anak, ketertarikan terhadap bayinya kurang, tidak berespon positif terhadap bayi dan malas menyusui. Sehingga akan mempengaruhi kesehatan, pertumbuhan dan perkembangan sang bayi.

Kejadian DPP masih cukup tinggi, hal ini ditunjukkan dengan prevalensi kejadian depresi postpartum di Pakistan sebesar 22,3\% (Tikmani S et al, 2016). Prevalensi DPP di Yunani sebesar 13,6\% di (Koutra et al, 2018). Di Wilayah Kabupaten Klaten, sebanyak 30\% mengalami DPP ringan dan 6,7\% mengalami DPP sedang (Imanditya \& Murwati, 2014). Di Surakarta sebanyak 52\% responden mengalami depresi postpartum (Ria et al, 2018). Gejala yang sering muncul pada DPP adalah perasaan sedih, menangis, cepat tersinggung, cemas, sulit untuk berkonsentrasi, labilitas perasaan serta gangguan tidur dan nafsu makan, lebih berat lagi ditemukan ada pikiran bunuh diri, waham paranoid dan melakukan ancaman kekerasan terhadap bayinya (Bobak, 2005).

Faktor penyebab DPP cenderung kompleks dan masih belum jelas. Perubahan hormonal pasca persalinan ditengarai berhubungan dengan symptom depresif dan faktor biologis yang dapat menjelaskan terjadinya depresi pasca persalinan (Corey \& Tapha, 2011). Faktor yang mempengaruhi terjadinya depresi postpartum adalah adanya riwayat depresi, kegelisahan selama kehamilan, konflik perkawinan, adanya tekanan hidup atau pengalaman hidup tidak menyenangkan, dukungan sosial yang rendah, status ekonomi yang rendah dan adanya komplikasi obstetrik (Stewart, et al. 2003). Hasil penelitian sebelumnya menyatakan bahwa dukungan keluarga dan pekerjaan adalah faktor yang mempengaruhi depresi postpartum (Wahyuni.S, Supiati, Murwati, 2014). 
Meskipun secara khusus belum ada skreening dan upaya penanganan DPP, namun program pelayanan antenatal care dan kunjunan nifas yang dilakukan dengan cermat dan menyeluruh mampu mendeteksi masalah psikologis ibu nifas dengan baik. Oleh karena begitu kompleknya faktor yang diduga sebagai penyebab depresi postpartum maka perlu kiranya di ketahui faktor determinan terjadinya depresi postpartum. Adapun tujuan penelitian ini untuk mengetahui faktor determinan depresi postpartum di wilayah Kabupaten Klaten Jawa Tengah.

\section{TINJAUAN PUSTAKA}

Postpartum adalah masa beberapa jam sesudah lahirnya plasenta sampai minggu keenam setelah melahirkan. Masa post pertum dimulai setelah kelahiran plasenta dan berakhir ketika alat-alat kandungan kembali pada masa sebelum hamil yang berlangsung kira-kira enam minggu. Pendapat lain mengatakan postpartum adalah masa setelah kelahiran yang meliputi minggu-minggu berikutnya pada waktu saluran reproduksi kembali kekeadaan yang normal pada saat sebelum hamil. Depresi postpartum hampir sama dengan baby blues syndrom, perbedaannya terletak pada frekuensi, intensitas, serta durasi berlangsungnya gejala-gejala yang timbul. Pada saat mengalami depresi postpartum, ibu akan merasakan berbagai gejala yang ada pada baby blues syndrom, tetapi dengan intensitas yang lebih sering, lebih hebat, serta lebih lama.

\section{METODOLOGI PENELITIAN}

Desain penelitian ini menggunakan desain kasus kontrol untuk mengetahui pengaruh antara variabel independen dengan syndrome depression postpartum. Penelitian dilakukan pada tahun 2019 di Wilayah Kabupaten Klaten. Sampel adalah ibu nifas hari ke-3 s.d ke-7 dan tidak ada riwayat penyakit menular serta gangguan jiwa, sebanyak 105 orang dengan 35 orang kasus dan 70 orang kontrol (1:2) secara Purposive consequtive sampling. Data di ambil dengan kuisioner biodata dan EPDS atau Edinburg postnatal Depression Scale (McBride, 2014). Uji statistika dengan Chi-square. 


\section{HASIL DAN DISKUSI}

Tabel 1

Distribusi frekuensi faktor karakteristik dan psikososial pada ibu postpartum di Wilayah Klaten Selatan

\begin{tabular}{|c|c|c|c|c|}
\hline \multirow[t]{2}{*}{ Variabel } & \multicolumn{2}{|c|}{$\begin{array}{c}\text { Depresi } \\
\text { Postpartum } \\
\text { (kasus) }\end{array}$} & \multicolumn{2}{|c|}{$\begin{array}{l}\text { Tidak depresi } \\
\text { postpartum } \\
\text { (kontrol) }\end{array}$} \\
\hline & $\mathbf{n}$ & $\%$ & $\mathbf{n}$ & $\%$ \\
\hline \multicolumn{5}{|l|}{ Umur ibu saat melahirkan } \\
\hline$<20^{\text {th }}$ atau $>35^{\text {th }}$ & 9 & 25 & 9 & 13 \\
\hline $20-35^{\text {th }}$ & 26 & 75 & 61 & 87 \\
\hline \multicolumn{5}{|l|}{ Pekerjaan Ibu } \\
\hline Tidak bekerja & 11 & 31 & 20 & 29 \\
\hline Bekerja & 24 & 69 & 50 & 61 \\
\hline \multicolumn{5}{|l|}{ Paritas } \\
\hline Primipara & 12 & 34 & 32 & 46 \\
\hline Multipara & 23 & 66 & 38 & 54 \\
\hline \multicolumn{5}{|l|}{ Riwayat persalinan } \\
\hline Tindakan & 8 & 23 & 17 & 24 \\
\hline Spontan & 26 & 77 & 53 & 76 \\
\hline \multicolumn{5}{|l|}{ Kelancaran ASI } \\
\hline Tidak lancar & 6 & 17 & 14 & 20 \\
\hline Lancar & 29 & 83 & 56 & 80 \\
\hline \multicolumn{5}{|l|}{ Perencanaan Anak } \\
\hline Tidak direncanakan & 7 & 20 & 10 & 14 \\
\hline Di rencanakan & 28 & 80 & 60 & 86 \\
\hline \multicolumn{5}{|l|}{ Pekeriaan Rumah } \\
\hline $\begin{array}{l}\text { Tak ada yang } \\
\text { membantu }\end{array}$ & 26 & 74 & 56 & 80 \\
\hline Ada yang membantu & 9 & 26 & 14 & 20 \\
\hline Total & 35 & 100 & 70 & 100 \\
\hline
\end{tabular}

Berdasar tabel 1 diatas dapat disimpulkan bahwa responden didominasi oleh ibuibu berusia 20 - 35 tahun, ibu bekerja, mempunyai anak lebih dari satu, persalinan normal, ASI lancar, anak direncakan dan tidak mempunyai pembantu. Kondisi ini mengindikasikan bahwa responden baik kasus maupun kontrol setara secara karakteristik, riwayat dan kondisi kehidupan sehari hari. 
Tabel 2

Hasil uji bivariat karakteristik, psikososial serta riwayat persalinan yang berhubungan dengan syndrome depresi postpartum di Wilayah Puskesmas Klaten selatan

\begin{tabular}{lllc}
\hline Variabel & OR & $\begin{array}{c}\text { CI } \\
\text { 95\% }\end{array}$ & $\begin{array}{c}\text { Nilai } \\
\boldsymbol{P}\end{array}$ \\
\hline Umur ibu saat melahirkan & & & \\
Pekerjaan Ibu & 2.3 & $0.836-6.583$ & 0.099 \\
Paritas & 1.1 & $0.474-2.768$ & 0.762 \\
Riwayat persalinan & 0.62 & $0.267-1.437$ & 0.262 \\
Kelancaran ASI & 0.734 & $0.227-15.736$ & 0.363 \\
Perencanaan anak & 0.828 & $0.288-2.380$ & 0.725 \\
Dukungan orang terdekat & 1.5 & $0.517-4.351$ & 0.454 \\
\hline
\end{tabular}

Hasil uji bivariat menunjukkan hanya usia ibu saat melahirkan yang berpengaruh secara signifikan dengan depresi postpartum. Hal ini berarti bahwa usia ibu yang <20 dan >35 tahun saat melahirkan mempunyai risiko 2,3 kali mengalami depresi postpartum dibandingkan usia ibu 20 - 35 tahun saat melahirkan. Sedangkan enam variabel lainnya tidak berpengaruh secara statistik dengan depresi postpartum. Berdasarkan uji statistic tersebut diatas maka tidak dilanjutkan pengujian regresi logistik karena hanya ada satu variabel yang memenuhi syarat $\mathrm{p}<0,25$ yaitu variable umur.

Hasil analisa statistik didapatkan bahwa faktor yang terbukti berpengaruh terhadap terjadinya depresi postpartum adalah usia ibu $<20$ dan $>35$ tahun saat melahirkan, sedangkan pekerjaan, paritas, riwayat persalinan, kelancaran ASI, perencanaan anak dan keberadaan orang yang membantu pekerjaan sehari hari sesudah melahirkan tidak berpengaruh terhadap kejadian depresi postpartum. Sehingga dapat di simpulkan dalam penelitian ini secara statistik faktor determinan depresi postpartum adalah ibu yang berusia $<20$ dan $>35$ tahun saat melahirkan.

\section{Usia ibu saat melahirkan}

Hasil penelitian ini sesuai dengan beberapa penelitian sebelumnya bahwa pada usia ini adalah usia risiko terjadi gangguan secara fisik maupun psikologis ketika hamil dan melahirkan. Sebuah penelitian menyebutkan bahwa ada 
hubungan antara usia ibu dengan depresi postpartum (Putriarsih, Budihastuti dan Murti, 2018). Demikian juga penelitian lain menunjukkan ada hubungan antara umur ibu dengan postpartum bluesh (Kurniasari dan Astuti, 2015; Masithoh, Asiyah dan Naimah, 2019). Namun berbeda dengan beberapa penelitian lain yang menyatakan tidak ada hubungan umur ibu saat melahirkan tidak berpengaruh terhadap depresi postpartum (Wahyuni, Murwati dan Supiati, 2014; Fazraningtyas, 2019; Nurfatimah, Entoh, 2018; Koutra, et al, 2018).

Wanita pada usia <20 tahun berrisiko mengalami gangguan kesehatan apabila hamil dan melahirkan. Hal ini di karenakan secara fisik organ-organ kewanitaan saat usia ini sedang berkembang dan belum berfungsi secara sempurna sehingga belum siap seratus persen untuk menerima pembuahan hingga kehamilan. Bahkan bisa meningkatkan risiko tekanan darah tinggi, pada kondisi ini tidak jarang juga bisa menyebabkan kejang hingga kematian pada ibu. Demikian juga proses persalinan akan terganggu karena secara anatomi rongga panggul belum cukup besar untuk jalan lahir bayi. Selain gangguan kesehatan fisik, seorang wanita yang hamil diusia muda juga berisiko memiliki gangguan psikis yang lebih tinggi dibanding wanita yang hamil dan menikah pada usia matang. Hal ini berkaitan dengan kesiapan menghadapi peran baru sebagai ibu dan merawat bayinya. Sedangkan dari segi kesehatan bayinya, bayi lebih berisiko lahir dalam kondisi berat badan rendah dan berisiko tubuh pendek, selain itu tidak jarang juga bisa menghambat perkembangan otak, jantung dan pembuluh darah.

Wanita usia >35 tahun juga berisiko untuk hamil dan melahirkan. Beberapa risiko tersebut adalah kemungkinan melahirkan bayi dengan kondisi cacat bawaan lahir, lebih rentan mengalami keguguran, berisiko melahirkan bayi prematur atau lahir dengan berat badan rendah, rentan mengalami berbagai komplikasi kehamilan (seperti diabetes gestasional, preeklamsia), dan lebih rentan mengalami gangguan selama persalinan sehingga memerlukan operasi caesar. Faktor usia $<20$ dan >35 tahun ini memang tergolong usia yang risiko, tetapi tidak menutup kemungkinan wanita bisa hamil dan melahirkan dengan sehat pada usia ini dengan menjalani pola hidup sehat. Sehingga tidak menjadi heran bahwa dalam beberapa penelitian, faktor usia ini ada yang berpengaruh dan ada yang tidak berpengaruh terhadap kejadian depresi postpartum. Hal ini menunjukkan bahwa pemicu 
terjadinya depresi postpartum tidak hanya faktor usia saat hamil dan melahirkan tetapi bisa faktor yang lainnya.

Mengingat pentingnya risiko faktor usia ini maka perlu upaya yang serius untuk menangani hal ini agar tidak terjadi depresi postpartum. Edukasi kepada masyarakat tentang risiko pernikahan dini menjadi pilihan untuk mencegah dan meminimalkan risiko ini. Demikian juga konseling prahamil menjadi pilihan yang baik untuk menyiapkan kehamilan dan persalinan yang berkualitas bagi wanita yang terlanjur hamil dan melahirkan di usia ini.

\section{Paritas}

Hasil penelitian ini menunjukkan bahwa paritas tidak berpengaruh terhadap kejadian depresi postpartum. Sebagaimana beberapa penelitian sebelumnya yang menyatakan paritas merupakan salah satu faktor risiko terjadinya depresi postpartum, terutama kelahiran yang pertama (primipara). Sebuah studi membuktikan bahwa ibu primipara, berisiko 2 kali mengalami depresi postpartum (Tikmani et al, 2016). Demikian juga penelitian lain menunjukkan bahwa ada hubungan antara paritas dengan depresi postpartum (Nurfatimah, Entoh, 2018). Begitu juga sebuah penelitian di Spanyol menunjukkan bahwa primipara lebih cenderung memiliki masalah gejala depresi, kecemasan dan kesedihan (Martinez et al, 2019). Namun, hasil penelitian ini sejalan dengan hasil penelitian lain yang mengatakan bahwa paritas tidak ada hubungan dengan kejadian depresi postpartum (Putriasih et al 2018, Koutra et al 2018). Hal ini dikuatkan sebuah penelitian bahwa tingkat depresi tidak berbeda bemakna antara wanita primipara dan multipara baik sebelum maupun sesudah melahirkan (Bassi et al, 2017).

Paritas atau jumlah anak yang dilahirkan hidup merupakan pengalaman yang luar biasa bagi seorang ibu. Hal ini berkaitan dengan perubahan yang terjadi baik secara fisik, psikologis maupun sosial sejak ibu hamil hingga melahirkan dan menyusui. Kelahiran anak pertama, sekalipun anak yang sangat diinginkan dan direncanakan, pada kenyataannya tetap mengganggu kondisi psikologisnya. Hal ini berkaitan dengan tingkat kesiapan ibu yang baru pertama kali melahirkan dan mengalami perubahan peran. Sedangkan kelahiran anak kedua dan selanjutnya, 
meski secara statistik banyak penelitian yang mengatakan bahwa multipara tidak menjadi faktor risiko, namun sebuah penelitian mendapatkan selisih prevalensi yang sedikit yaitu 25\% primipara mengalami depresi berat pasca melahirkan dan multipara 20\% (Sari, 2020). Demikian juga dalam penelitian ini ditemukan sebanyak 66\% multipara mengalami gejala depresi postpartum. Ibu multipara bisa mengalami gejala depresi diduga berkaitan dengan pengalaman buruk melahirkan sebelumnya, ketidak nyamanan yang dialami dan kelelahan paska melahirkan. Sebagaimana hasil penelitian bahwa hubungan antara faktor risiko kognitif dan interpersonal serta gejala depresi dan kecemasan terbukti sama antara multipara dan primipara. Selain itu kondisi tersebut di dukung adanya laporan tingkat dukungan sosial dan kepuasan pernikahan yang rendah (Sockol, 2015).

\section{Pekerjaan}

Pekerjaan ibu nifas dalam penelitian ini terbukti tidak berhubungan dengan kejadian depresi postpartum. Hasil ini sejalan dengan penelitian lain bahwa tidak ada hubungan antara pekerjaan dengan depresi postpartum (Fazraningtyas, 2019). Namun sebaliknya hasil ini tidak sesuai dengan beberapa penelitian lain yang menyatakan terdapat hubungan antara pekerjaan dengan kejadian depresi postpartum (Kusuma, 2017). Responden yang tidak bekerja berisiko 3,684 kali lebih besar untuk mengalami post partumblues (Kurniasari, Astuti, 2015). Penelitian sebelumnya menunjukkan bahwa ibu yang tidak bekerja berisiko 10 kali lipat terjadi depresi postpartum (Wahyuni, supiati, Murwati, 2014).

\section{Perencanaan anak}

Hasil uji statistik menunjukkan bahwa perencanan anak tidak berpengaruh terhadap kejadian depresi postpartum. Hal ini sesuai penelitian lain bahwa tidak ada hubungan antara kehamilan yang tidak direncanakan dengan antenatal dan postpartum depresi (Faisal et al., 2016). Namun beberapa penelitian lain menunjukkan bahwa kehamilan yang tidak di inginkan berhubungan dengan postpartum (Putriarsih, Budihastuti dan Murti, 2018; Ria, Budihastuti dan Sudiyanto, 2018; Dira dan Wahyuni, 2016). Begitu juga dengan hasil penelitian lain 
menyatakan bahwa kehamilan yang tidak di inginkan akan berrisiko 2, 8 kali terjadi depresi postpartum (Tikmani, Somroo, Tikmani, 2016).

\section{Riwayat persalinan}

Hasil uji statistic menunjukkan bahwa riwayat persalinan tidak ada hubungan dengan depresi postpartum. Hal ini sejalan dengan penelitian Wahyuni et al 2014. Penelitian lain menujukkan bahwa tidak ada hubungan yang bermakna antara komplikasi kehamilan dengan kejadian post partum blues (Kurniasari \& Astuti, 2015). Namun hasil ini tidak sesuai dengan sebuah penelitian yang menunjukkan bahwa komplikasi dalam persalinan berisiko 7.5 kali mengalami depresi postpartum (Tikmani, Somroo, Tikmani, 2016).

Gangguan postpartum berkaitan riwayat obstetri pasien meliputi riwayat hamil sampai bersalin serta apakah ada komplikasi dari kehamilan dan persalinan sebelumnya. Selain itu, depresi postpartum juga dapat disebabkan oleh pengaruh dari jenis persalinan. Penelitian yang dilakukan oleh Ariyanti membuktikan bahwa ibu dengan persalinan bedah lebih banyak mengalami depresi postpartum dibandingkan dengan persalinan pervagina. Hal tersebut terjadi karena proses penyembuhan dari persalinan bedah memakan waktu yang cukup lama sehingga menghambat ibu untuk menjalani peran barunya (Ariyanti, Nurdiati, \& Astuti, 2016). Begitu juga menurut sebuah penelitian yang menunjukkan bahwa komplikasi saat prsalinan berhubungan dengan depresi postpartum (Putriarsih, Budihastuti dan Murti, 2018).

\section{Kelancaran ASI}

Kelancaran ASI pada dua minggu pertama setelah melahirkan terbukti tidak ada hubungan dengan depresi postpartum. Hal ini tidak sesuai dengan penelitian sebelumnya bahwa durasi menyusui kurang dari 2 bulan dikaitkan dengan peningkatan 77\% kemungkinan PPD (OR = 1,77, 95\% CI: 1,19, 2,64) (Koutra et al, 2018). Demikian juga penelitian lain yang hampir sama menyatakan ada hubungan antara kelancaran pengeluaran ASI dengan Postpartum Blues di Wilayah Puskesmas Trucuk II Klaten (Suparwati, Murwati, dan Suwanti, 2018). Penelitian lain juga menunjukkan bahwa ibu postpartum dengan gejala depresi dapat 
mempengaruhi keberhasilan ASI eksklusif dikarenakan ada perubahan hormon dan mood (perasaan) yang terjadi pada ibu seperti ibu tidak nafsu makan, gangguan tidur, cemas, sensitif sehingga dapat mengganggu kelancaran ASI (Arami, Mulasari dan Hani, 2021).

\section{Keberadaan orang yang membantu pekerjaan sehari hari sesudah melahirkan}

Keberadaan orang yang membantu menyelesaikan atau meringkan pekerjaan ibu sesudah melahirkan adalah salah satu bentuk dukungan keluarga dekat termasuk suami. Hasil uji statistik menunjukkan tidak ada hubungan antara kondisi tersebut dengan depresi postpartum. Hal ini tidak sejalan penelitian lain yang menyatakan bahwa ada hubungan dukungan social meliputi keluarga dengan depresi postpartum (Nurfatimah \& Entoh, 2018). Begitu juga penelitian lain mengatakan bahwa dukungan atau bantuan yang tidak memuaskan untuk perawatan bayi berisiko 4.89 mengalami depresi postpartum (Ghogomu et al, 2015).

Faktor determinan dalam penelitian ini secara statistik adalah usia saat ibu melahirkan <20 dan >35 tahun. Meskipun faktor lain yang diteliti tidak berpengaruh secara statistik namun bukan berarti faktor tersebut diabaikan. Hal ini dikarenakan gangguan psikologis pada ibu nifas rentangnya cukup luas begitu juga faktor risikonya yang dikategorikan mulai dari demografi, psikologi, sosial, obstetrik dan faktor bayi. Selain itu beberapa faktor unik lainnya seperti hubungan dengan mertua, belum memiliki anak laki laki ataupun jenis kelamin bayi yang tidak diharapkan bias memicu terjadinya depresi postpartum (Savitha el al, 2018).

Upaya yang dapat dilakukan salah satunya memberi dukungan positif karena semakin tinggi tingkat kesejahteraan psikologi ibu maka tingkat depresi makin menurun (Bassi et al, 2017). Sejalan dengan hasil penelitian bahwa dukungan faktor yang paling dominan berhubungan dengan depresi pascasalin (Nurfatimah \& Entoh, 2018). Selain itu penerapan psikoedukasi dengan CBT dapat mencegah terjadinya depresi postpartum (Murwati \& Suroso, 2017). 


\section{KESIMPULAN}

Faktor yang terbukti berpengaruh terhadap terjadinya depresi postpartum adalah usia ibu $<20$ dan $>35$ tahun saat melahirkan, sedangkan pekerjaan, paritas, riwayat persalinan, kelancaran ASI, perencanaan anak dan keberadaan orang yang membantu pekerjaan sehari hari sesudah melahirkan tidak berpengaruh terhadap kejadian depresi postpartum. Sehingga dapat di simpulkan dalam penelitian ini secara statistik faktor determinan depresi postpartum adalah ibu yang berusia $<20$ dan $>35$ tahun saat melahirkan.

\section{DAFTAR PUSTAKA}

Ardiyanti, D., \& Dinni, S. M. (2018). Aplikasi Model Rasch dalam Pengembangan Instrumen Deteksi Dini Postpartum Depression. Jurnal Psikologi, 45(2), 81.

Ariyanti, R., Nurdiati, D. S., \& Astuti, D. A. Sari. (2016). Pengaruh Jenis Persalinan Terhadap Risiko Depresi Postpartum. Jurnal Kesehatan Samodra Ilmu, 7(2), 98- 105.

Arami N, Mulasari M A, Hani U. (2021). Gejala depresi postpartum mempengaruhi keberhasilan asi eksklusif. Jurnal Kesehatan Kusuma Husada.

Bassi M, Fave A D, Cetin.I, Melchiorri E, Pozzo M, Vescovelli F. (2017). Psychological well-being and depression from pregnancy to postpartum among primiparous and multiparous women. 183-195.

Bobak. (2005). Buku Ajar Keperawatan Maternitas. Edisi 4. Jakarta : EGC.

Corey E \& Thapa S. (2011) Postpartum Depression: An Overview of Treatment and Prevention : World Health Organization Department of Reproductive Health and Research. Geneva.

Dira, Wahyuni. (2016). Prevalensi dan faktor risiko depresi postpartum di kota denpasar menggunakan edinburgh postnatal depression scale. e-jurnal medika, 5 (7) : 1-7. 
Elvira S. D., Ismail, R. I., Moegni, F., \& Herqutanto. (2013). Deteksi, Pencegahan dan Tata Laksana Depresi pada Ibu Hamil dan Pascapersalinan. Majalah Kedokteran Indonesia, 63, 207-212.

Fazraningtyas, W A. (2019). Hubungan Faktor Socio demographic Dengan Depresi Postpartum Di Rumah Sakit Daerah Banjarmasin. Dinamika Kesehatan Jurnal Kebidanan dan Keperawatan, 17 (2), 47 - 55.

Fitelson E, Kim S, Baker A and Leight K. (2011). Treatment of Postpartum Depression: Clinical, Psychological and Pharmacological Options. International Journal of Women's Health, 3 (1), 1-14.

Ghogomu G., Halle-Ekane, G. E., Nde, P. F., Palle, J., Atashili, J., Mangala, F. N., \& Nsagha, D. (2015). Prevalence and Predictors of Depression among Postpartum Mothers in the Limbe Health District, Cameroon: A CrossSectional Study. Journal of Advances in Medicine and Medical Research, 12(3), 1-11.

Imaninditya P.W, Murwati. (2014). Studi diskriptif tingkat depresi postpartum pada ibu nifas di wilayah kerja puskesmas klaten selatan. Jurnal Kebidanan Indonesia (Journal of Indonesia Midwifery), 5 (1).

Koutra.K, et al. (2018). Pregnancy, perinatal and postpartum complications as determinants of postpartum depression: the Rhea mother-child cohort in Crete, Greece.Epidemiol Psychiatr Sci, 27(3): 244-255.

Kusuma, P. D. (2017). Karakteristik Penyebab Terjadinya Depresi Postpartum pada Primipara dan Multipara. Jurnal Keperawatan Notokusumo, 5(1), 36-45.

Kurniasari, D., \& Astuti, Y. A. (2015). Hubungan Antara Karakteristik Ibu, Kondisi Bayi dan Dukungan Sosial Suami dengan Postpartum Blues pada Ibu Dengan Persalinan SC di Rumah Sakit Umum Ahmad Yani Metro Tahun 2014. Jurnal Kesehatan Holistik, 9(3), 115-125.

Martínez.J.M, Galiano. Hernández.A, Martínez. Rodríguez.J, Almagro, Delgado.M, Rodríguez \& Gómez.J, Salgado. (2019). Relationship between parity and the problems that appear in the postpartum period. Scientific Reports, $9: 11763$.

Mcbride, Hillary \& Wiens, Rachel \& McDonald, Marvin \& Cox, Daniel \& Chan, Eric. (2014). The Edinburgh Postnatal Depression Scale (EPDS): A review of the reported validity evidence. 10.1007/978-3-319-07794-9. 
Masithoh A R, Asiyah N, Naimah.Y. (2019). Hubungan Usia dan Pendidikan Ibu dengan Kejadian Post Partum Blues di Desa Mijen Kecamatan Kaliwungu Kabupaten Kudus. Research Colloqium. Sekolah Tinggi Ilmu Kesehatan Muhammadiyah Gombong.

Murwati dan Suroso. (2017). Penerapan cognitif behavior therapi (cbt) pada ibu nifas sebagai upaya pencegahan depresi post partum di Kabupaten Klaten. Jurnal Kebidanan Dan Kesehatan Tradisional, 2 (2) : 60-115.

Norhayati MN, Hazlina NH, Asrenee AR, Emilin WM. (2015). Magnitude and risk factors for postpartum symptoms: a literature review. J Affect Disord. 1;175:34-52. doi: 10.1016/j.jad.2014.12.041.

Nurfatimah, Entoh.C. (2018). Hubungan faktor demografi dan dukungan sosial dengan depresi pascasalin. Jurnal Profesi Medika, 11, (2) : 2621-1122.

Nasri, Z., Wibowo, A., \& Ghozali, E. W. (2017). Faktor Determinan Depresi Postpartum di Kabupaten Lombok Timur. Buletin of health system, 20(3), 8995.

Putriarsih.R, Budihastuti.U.R, Murti.B. (2018). Prevalence and Determinants of Postpartum Depression in Sukoharjo District, Central Java. Journal of Maternal and Child Health, 3(1) 11-24. https://doi.org/10.26911/thejmch.2018.03.01.02

Ria B, Budihastuti U R, Sudiyanto A. (2018). Risk Factors of Postpartum Depression at Dr. Moewardi Hospital Surakarta. Matilda Journal of Maternal and Child Health, 3(1): 81-90.

Riyanto, A. (2012). Penerapan Analisis Multivariat dalam Penelitian Kesehatan (dilengkapi Contoh kasus Serta Aplikasi Program SPSS \& Excel). Kota: Nuha Medika.

Savitha, George LS, Shyamala G, Noronha JA, Mayya S. (2018). Associated risk factors of postnatal depression in South Asian region - a narrative review. Manipal Journal of Nursing and Health Science, 4(1), 45-48.

Sari R A. (2020). Literature Review: Postpartum Depression. Jurnal Kesehatan, 11 (1), $167-174$. 
Sockol, L.E., Battle, C.L. (2015). Maternal attitudes, depression, and anxiety in pregnant and postpartum multiparous women. Arch Womens Ment Health 18, 585-593 (2015). https://doi.org/10.1007/s00737-015-0511-6.

Suparwati I, Murwati, Suwanti E. (2018). Hubungan antara kelancaran pengeluaran ASI dengan kejadian postpartum blues di wilayah puskesmas trucuk II klaten. Jurnal Kebidanan Dan Kesehatan Tradisional, 3 (1), 1-56.

Stewart, D.E., Robertson, E., Dennis, CL., Grace, S.L., \& Wallington, T. (2003). Postpartum depression: Literature Review of Risk Factors and Interventions. Toronto Public Health.

Tikmani, S. S., Soomro, T., Tikmani, P. (2016). Prevalence and Determinants of Postpartum Depression in a Tertiary Care Hospital. Austin Journal of Obstetrics and Gynecology, 3(2), 1-5.

Wahyuni S, Murwati, Supiati. (2014). Faktor internal dan eksternal yang mempengaruhi depresi postpartum. Jurnal Terpadu Ilmu Kesehatan, 3 (2), 106-214. 